\title{
The Translatability of Prosody: A case study of English/Arabic Poetry
}

\section{Aya Awad Shehata Mabruk* \\ aa208@fayoum.edu.eg}

\section{Abstract:}

This paper investigates the translatability of prosody by showing the difficulty of translating the prosodic features from English into Arabic, illustrated with English/ Arabic examples. The current study is intended to show that prosody presents a challenge for translators in translating the poetic text from English into Arabic due to the great differences between the two linguistic systems. The dictionary definition of rhythm is the regular occurrence of sounds, that is the sonic pattern created by successive variously intonated units of speech, mainly by using syllables usually stressed and unstressed in a certain order, in European languages, such as English, French and German. In Arabic we have units of consonants and vowels, rather than syllables, with less consideration for intonation. So, while we have in English a line consisting of a number of successive syllables creating units of one unstressed followed a stressed syllable, in Arabic we have units consisting of one, two, or more consonants followed by a vowel. This paper concludes that failure to preserve prosodic features such as rhythm, meter, and rhyme

\footnotetext{
* Department of English Language and Literature, Faculty of Arts, Fayoum University.
} 
is due to the employed strategy that the translator used either to translate the poetic text into verse or prose style.

Keywords: prosody - NrhythmN - consonantsN - vowels - syllables - stressed - unstressed

\section{Introduction:}

The English unit for which the symbol of $(u-)$ is used [the ' $u$ ' means unstressed], is called a 'foot'. In Arabic the unit consisting of two consonants followed by a vowel and one consonant followed by a vowel, for which the symbol is (-$\mathrm{o}-\mathrm{o}$ ) [the dash is a consonants and the 'o' is a vowel], is called (تفعيلـة) and may be regarded as the equivalent of a foot in English. Shorter Arabic 'feet' are available, the commonest one may consist of three consonants followed by a vowel ($--\mathrm{o})$ or alternating consonants and vowels $(-\mathrm{O}-\mathrm{o})$.

In Arabic, however, the vowel is either a long 'Alef', 'Waw' or 'Yaa' (أ-و - - أ) or a stopped consonant, that is a consonant not followed by any vowels, short or long. Take for example a sentence in Arabic like (مَنْ تَكُنْ لِلي) which is transcribed in English as (man takon lee) is regarded, for the purpose of phonetic enunciation needed for the recognition of the rhythm as $(-\mathrm{o} /--\mathrm{o} /-\mathrm{o})$ where the initial (ميم) (m)

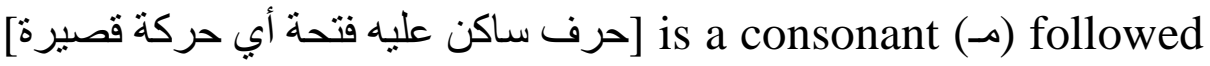
by a short vowel, thus ( (o) [سكون] is regarded as a vowel, that is a stop consonant, and is therefore a vowel. The same applies to the following word where $(\mathrm{ta})[\overrightarrow{-}]$ is a consonant followed by a short vowel, and the (k) (5) is a consonant followed by a short 
vowel (o) - (ta ko n). The last word consists of an (L) (ل) (لام] followed by a long vowel. Hence the rhythm $(-\mathrm{o} /--\mathrm{o} /-$ o).

\section{Arabic Prosody:}

Consequently, a word like (أَفْْْن ) Aqbel is said to consist of a hamzat, followed by a short vowel $(s+$ a) the $Q$ is a stopped consonant and is therefore a vowel, the (b) (ب) is a consonant followed by a short vowel, and is therefore a consonant, then the (L) (لام) is a stop consonant and is therefore a vowel. The phonetic transcription of the word would be $(-\mathrm{O}-\mathrm{o})$ with each letter is represented by a single dash or 'o'. The unit is a whole is regarded as a foot, and may be repeated - as a sonic pattern called metre (البحر الثـعري). This foot has different forms but equally regular, such as (-- o) as in the word kutuba (where $k u$ and $t u$ and $b$ are consonants, followed by the long vowel (a) (كُنَبَ). It is to be noted that what counts in Arabic verse is the phonetic not the written form of the word. So, if the word was (كتبًا) it is transcribed phonetically as kutuban, without any change in the rhythm. So, a monostich (شطر) that is, a hemistich (نصف بي) like:

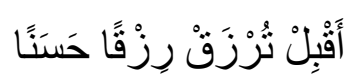

(Aqbel turzaq rizqan hasana)

Would be symbolized by $(\rightarrow-0-0 /-0-0 /-0-0 /---$ o /) where the last word consists of three consonants followed by the vowel - either (a) or (an). 


\section{Arabic / English Prosody:}

A famous example of the regular metre in English is a 'pastoral' (رعويـة) poem by Christopher Marlowe. Here is the opening line:

Come live with me and be my love

When you read it normally, you find that the second word is always stressed, the first always unstressed. Each word is an independent syllable, and each combination of two such syllables makes a foot, whose rhythm is $(\mathrm{v}-)$ which we call iambic. When you read the stressed syllables, you can get some sort of meaning, which is the opposite of the combination of the unstressed syllables:

Live / me / be / love /

Come / with / and / my /

The stressed syllables are operative words, a verb, an object, an infinitive and a noun. The unstressed syllables are mostly inoperative. So, the pattern lakes the following form: $[\mathrm{v}-/ \mathrm{v}$ $-/ \mathrm{v}-/ \mathrm{v}-/]$. As there are four feet in the line, we call it tetrameter (رباعي). This is how we make it.

$$
\mathrm{V}-\mathrm{V}-\mathrm{V}-\mathrm{V}-
$$

Come live with me and be my love

$$
\mathrm{x}-\mathrm{x}-\mathrm{x}-\mathrm{x}-
$$

If we reproduce the line in Arabic, we may do it in prose, saying for instance: 


\section{أقبل ولنعش معًا ولتصبح حبيبي}

As prose the line has no pattern of any bind: transcribed phonetically it may look like:

(from right to left)
$\mathrm{o} / \mathrm{o} / / / \mathrm{o} / / \mathrm{o} / / \mathrm{o} / / \mathrm{o} / \mathrm{o} / \mathrm{o} /$

In other words, no recognizable units are repeated. If we translated it into verse, we may have:

$$
\text { أَفَبْلْ شَتَرِكْنِي عَبْنِي يا حُبِّي }
$$

Which would be thus phonetically transcribed:

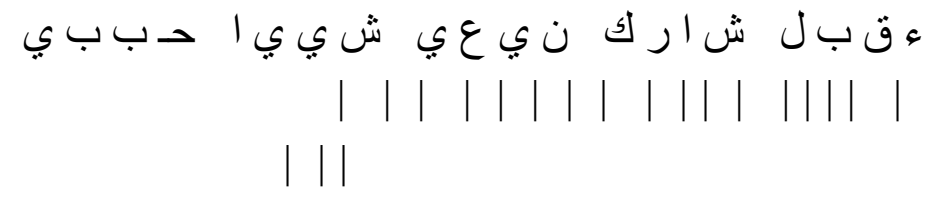

(from right to left) $\mathrm{o} / \mathrm{o} / \mathrm{o} / \mathrm{o} / \mathrm{o} / \mathrm{o} / \mathrm{o} / \mathrm{o} / \mathrm{o} / \mathrm{o} /$

Note that (حبي) is transcribed phonetically as (حُ بْ بِ ين). This should be enough to indicate the meaning of rhythm in both English and Arabic. Now for actual examples firm the English lyrics.

\section{Translating Metre:}

A famous ditty by Robert Burns reads:

$\mathrm{O}$ my luve is like a red red rose

That's newly sprung in June

$\mathrm{O}$ my luve is like a melody 
That's sweetly played in tune.

The initial 'o' in lines 1 and 3 is an extra syllable that does not count in the scansion, so that the line consists of four feet, each consisting of one unstressed syllable followed by a stressed one $(\mathrm{u}-)$ thus

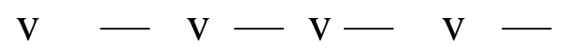

my luve is like a red red rose

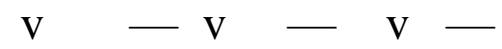

That's newly sprung in June

$\mathrm{v}-\mathrm{v}-\mathrm{v}-\mathrm{v}-$

my luve is like a melody

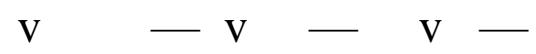

That's sweetly played in tune.

This means that the first line is tetrameter (four feet) followed by a line of three feet only (trimester). The remaining lines follow the same pattern. The rhythm is called iambic and is described as a rising beat (إيقاع صاعد). As modern stylisticians affirm, the meaning of the poem includes the rhythm as well as the imagery conveyed by the words. So, if you translate the words only, you will have conveyed only part of the meaning. According to Enani 2020, we will take this example: 


$$
\begin{aligned}
& \text { حبيني تشبه وردة حمر اء قانية } \\
& \text { تفتحت حديثًا في شهر يونيو } \\
& \text { حبييتي تشبه لحنًا } \\
& \text { معزوفًا بحلاوة وفق النغمة }
\end{aligned}
$$

This prose version looks like a paraphrase but fails to give us the full meaning of the poem. If we, however, do it in verse, the meaning is more likely to be complete:

$$
\begin{aligned}
& \text { حبييتي شبيهة بوردة حمر اء قدز هت بلونها } \\
& \text { تفتحت في الصبف هذا اليوم فوق غصنها } \\
& \text { حبييتي أنشودة جمالها في لحنها } \\
& \text { تو افقت أنغامها وذا رنين حسنها }
\end{aligned}
$$

The metre here will be different from the previous one (called khabab) but will be another Arabic metre called Rajaz (الرَّجَزَ). The rajaz foot could consist of two short syllables, followed by a long one, or two long syllables. The syllable in Arabic is necessarily different from an English one: it may be called a segment, as it consists of a single vowel, as in $\mathrm{min}$ (ن) where the vowel is represented by the stop consonant, or an ordinary vowel, like (مـ) maa; each is referred to as "stop" (سكون), and the segment in this case is regarded as short. It is the kind of segment that is repeated 10 times in the line (أقبـل given above. The long segment consists of a consonant followed by a short vowel (ma) (تَ) then by another followed by a "stop" - such as takun (تَعُنْ). Put together, the three segments would be something like maa lam takun (مالم تكن) the symbol of which is (from right to 
left): $[\mathrm{o} / / \mathrm{o} / \mathrm{o} /]$. The three segments are together called a foot of the rajaz metre. It is repeated in the hemistich (الثطر ) three times, normally, thus

$$
\begin{aligned}
& \text { مَاْ لَمْ نَكُنْ عِنْدِيْ أَنَاْ ل لا تَنْسنَيْ } \\
& \mathrm{o} / / \mathrm{o} / \mathrm{o} / \\
& \mathrm{o} / / \mathrm{o} / \mathrm{O} / \mathrm{o} / / \mathrm{o} / \mathrm{o} /
\end{aligned}
$$

Now, there are acceptable modulations (زحافـات) in both Arabic and English prosody (العروض). In English we may have a modulation of the iambic foot $(\mathrm{v}-)$ into the reverse beat $(-0)$ called trochee, and the adjective is trochaic. In Arabic, we may have two long segments in a foot instead of two short ones followed by a long one, thus (حَـبــيْ بَتِين ) from right to left $[\mathrm{o} / / \mathrm{o} / /]$. So, the rhythm of the versified translation of Burns' ditty would be:

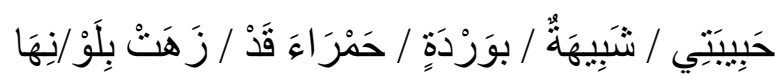

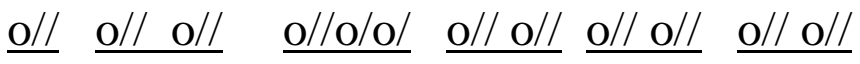

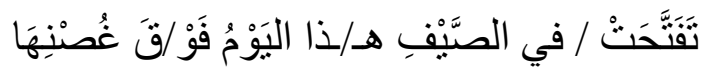

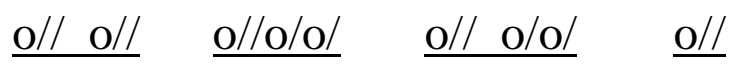

$$
\begin{aligned}
& \underline{\mathrm{o} / /}
\end{aligned}
$$

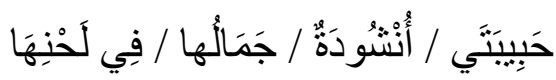

$$
\begin{aligned}
& \mathrm{o} / / \mathrm{O} / \mathrm{O} / \mathrm{o} / / \mathrm{O} / / \mathrm{o} / / \mathrm{o} / \mathrm{O} / \mathrm{o} / / \mathrm{O} / /
\end{aligned}
$$

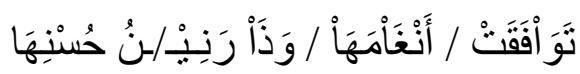

$$
\begin{aligned}
& \underline{\mathrm{o} / / \mathrm{o} / /} \quad \underline{\mathrm{O} / / \mathrm{o} / /} \quad \underline{\mathrm{o} / / \mathrm{o} / \mathrm{o} /} \quad \underline{\mathrm{o} / / \mathrm{o} / /}
\end{aligned}
$$

An advocate of 'formalism' may demand that the four Arabic lines be of equal length as is the tradition normally observed in Arabic verse, but this rule is no longer applied in modern poetry. If applied, the first line should read: 


$$
\begin{aligned}
& \text { حبيني شبيهة بوردة حمراء ق قانية } \\
& \mathrm{O} / / \quad \mathrm{O} / / \mathrm{O} / \mathrm{O} / \quad \mathrm{O} / / \mathrm{O} / / \quad \mathrm{O} / / \mathrm{O} / / \\
& \mathrm{o} / / \mathrm{o} / /
\end{aligned}
$$

Or even in less words:

$$
\begin{aligned}
& \text { حبيني / كالوردةٍ / الحمراءِ زاهِ / ل لونُها } \\
& \mathrm{o} / / \mathrm{o} / \mathrm{o} / \quad \mathrm{O} / \mathrm{o} / \mathrm{o} /
\end{aligned}
$$

$\mathrm{o} / / \mathrm{O} / \mathrm{O} / \quad \mathrm{O} / / \mathrm{O} / /$

But as the (n) (النون) is followed here by a short 'o', the whole rhyme scheme has to be changed. If not, it may be regarded as 'flawed', and the flaw is called (إقواء). If the first alternative is chosen, the second line should have a different rhyme:

$$
\begin{array}{r}
\text { تفتحت / لتو ها /في شهر يوني/و زاهية } \\
\text { o//o/o/ o/o/ } \\
\text { o//o// o//o// }
\end{array}
$$

The point is that rhyme and rhythm have come, according to modern stylistics, part of the meaning of the text. This is the prevalent view now, as discussed in detail by Stockwell (2009) and (2012-2014), confirmed by Sotirova (2016), and corroborated by Browse (2018). Rhyme and rhythm have to be changed as the phonology of the target language is necessarily different: So, while the metre changes from tetrameter to trimeter, from the odd-numbered lines to the even-numbered ones, the Arabic translated text consists of equal 4-foot lines, i.e. tetrameters. Sometimes the translator follows the source text if the alternation of meters appears significant to him or her. An example is the so-called "sublime epitaph' by Wordsworth: 
A slumber did my spirit seal

I had no human fears

She seemed a thing that could not feel

The touch of earthly years

No motion has she now no force

She neither hears nor sees

Rolled round in earth's diurnal course

With rocks and stones and trees.

The alternation of tetrameters and trimeters, thus

$\mathrm{v}-\mathrm{v}-\mathrm{v}-\mathrm{v}-$

A slumber did my spirit seal

$\mathrm{v}-\mathrm{v}-\mathrm{v}-$

I had no human fears

Is reflected in the Arabic version:

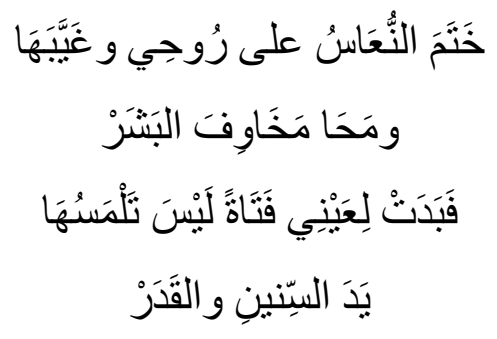

The odd-numbered lines belong to a complex metre called alBaseet (البسط) while the even-numbered belong to the rajz, but this only occasional, or even accidental, as the rest of the poem shows. 


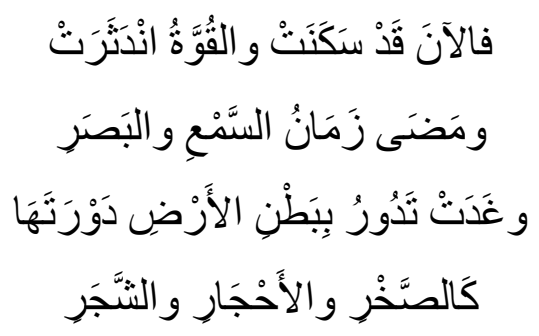

Here we have variations of al-Baseet and the rajaz (or alkaamil). The first line is a straightforward Baseet, the second a modulated kaamil, the third Baseet and the fourth the same as the second. Vital to this rendering is the unity of the main rhyme (البشر / القر / البصر / الشجر) which establishes the sonic leitmotif, further bolstered by the (ha) (ها) rhyme in lines 1, 3 and 7. So, as the rhythm and rhyme help to bind the lines together in the English text, they do so in the Arabic text producing the textual cohesion, which is conducive to coherence, with variation in the metre and the rhyme scheme. Note that the caesura in line 5 (the internal rhyme dividing the line into two equal parts) supports the deictic change from the 'I' of the speaker to the dead girl. Part of the unity of the poem is therefore due to the behaviour of the language, both as rhyme and rhythm. Without these two factors, the meaning of the poem would be incomplete.

Sometimes the poet builds a poem in the form of a series of quasi-conditionals, followed by what looks like a conclusion. The main feature here is parallelism: each distich consists of a premise (بيت شعري من سطرين) (مقدمة) and a result (نتيجة). The structure in toto looks like a sustained figure of speech. An example is Shelley's famous poem "Music ..."

Music when soft voices die 
Vibrates in the memory

Odours when sweet violets sicken

Live in the sense they quicken

Rose leaves when the rose is dead

Are heaped for the beloved's bed;

And so thy thoughts when thou art gone

Love itself shall slumber on.

The rhythm of the lines sounds regular enough, though we have variation in the number of syllables used in the eight lines, 7,7, 8,8, 7,8 and 7,8. This is said by Stockwell to constitute "subtle variations" which serve to "prevent the repetitions becoming monotonous" (2012, p.71). Monotony Was once regarded as extreme regularity required in every Arabic poem of the classical type; it is today avoided in most modern Arabic poetry. Instead of prosodical regularity, Arabic poetry relies on internal regularity, as Shelley's poem clearly shows. Each distich consists of a noun phrase (NP), a conjunction (conj), another noun phrase consisting of a pre-modifier and a noun $($ pre-mod+N), a verb phrase (VP), plus another VP, a preposition (prep), then a noun phrase (NP). The following is Stockwell's analysis:

There is syntactic repetition here, in the form of a brief initial noun phrase > followed by a relative clause with a conjunction 'when', a pre-modified noun phrase and a verb phrase $>$ followed by a main verb phrase $>$ and ending with a prepositional 
phrase consisting of a preposition and a noun phrase. There is also some parallelism across the semantic relationships of these lines. For example, the initial NP emerges from the NP in the relative clause (music comes from voices, odours come from violets, rose leaves come from the rose). There is, of course, some variation within these basic repetitions: the lexical realization of the initial NP ('music') is not repeated; though the conjunction 'when' is repeated, the later preposition is varied ('in, within, for'); though the final NP always begins with a determiner, the rest of the NP is variable. An intense reading can examine the significances of the variation. For example, the semantic progression across the initial NPs goes across the senses from sound ('music') to smell ('odours') to a combined sight and touch ('rose leaves'), and this progression scales from most intangible to most material. Furthermore, at an iconic level, the single senses are referenced with a single lexical item here while the doubled sense is referenced with two words. A particularly intensive reader might even notice that the synaesthetic blending of sight and touch is iconically matched by the potential multivalence of the nouns 'rose' and 'leaves' as active verbs, where there is no such potential in the single-item occurrences 'music' or 'odours'. (2012, p. 69) 
The fact that there is variation in the linguistic structure of the poem is reflected in the prosodical pattern, phonologically approached. This means that the translator should aim at conveying the regularity of the metre and the modulations which account for the variations. A prose rendering of the lines cannot reproduce the variations because it cannot reproduce the regularity in the first place. A professional translator may render the lines in prose as follows:

$$
\begin{aligned}
& \text { عندما تموت الأصو ات العذبة } \\
& \text { تتردد ألحانها في الذاكرة } \\
& \text { و عندما تمرض البنفسجيات الحلوة } \\
& \text { يحيا شذاها في الحس الذي تحييه. } \\
& \text { و عندما تموت الوردة } \\
& \text { تجمع أور اقها فر اشثًا للمحبوب } \\
& \text { و هكذا فعندما تغيبين } \\
& \text { تغدو أفكارك فر اشثًا ينام فيه الحب }
\end{aligned}
$$

Grammatically and consequently structurally, the Arabic text is logical and idiomatic enough. We have parallel distichs, consisting of all the elements mentioned by Stockwell. No one may quarrel with the correspondence of the Arabic text with the source text communicatively, according to Newmark's distinction between communicative and semantic translation. A semantic translation, according to such a distinction, should reflect the internal pattern rhythmically and, therefore, phonologically. This may be achieved in a 
verse translation in which the foregrounding of the initial noun phrases is maintained, and an adequate interpretation of the concluding distich is provided. Critics are not agreed on the meaning of the word 'gone' in the penultimate line: some claim that it means 'dead', but most commentators assume that the poem was addressed to his wife Mary, who gave it the title "To - ", when it was published in 1822 (only after the poet's death, though it was written in 1821), and that 'gone' simply means "when you are away." The interpretation of "thy thoughts" in the verse rendering gives meaning to the whole poem. Here is the verse rendering by M. Enani:

$$
\begin{aligned}
& \text { المُوسِيقَى حِينَ نَمُوتُ الأَصْوَ اتُ العَذَبَةْْ }
\end{aligned}
$$

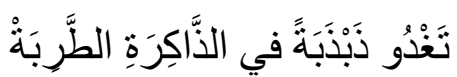

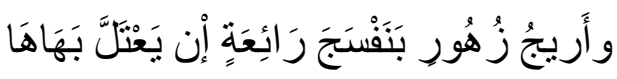

$$
\begin{aligned}
& \text { يَبْقَى حَيَّا في الإحْسَاسِ النَّابِض بِثَذَاَهَا }
\end{aligned}
$$

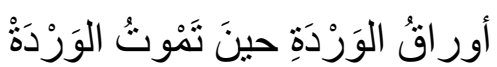

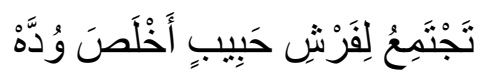

$$
\begin{aligned}
& \text { وكَذا إنْ غِبْتِ خَطَرْتِ بِنَالِي } \\
& \text { كَفِرَاشِ يَرْقُدُ فيه الحُبُُّ حِبَالِي }
\end{aligned}
$$

In our analysis, it has been noted that prosodic features are crucial in determining meaning in languages, and when it comes to translation, rendering these features should be given precedence over other cultural and linguistic features. The analysis shows that rendering prosody seems to be difficult as it is language-specific, a point with which Perego (2003) 
مجلة جامعة مصر للدراسات الإنسانية اللغويات والآداب ) مجلد 1 عدد 1 يناير (2021)

agrees. Since intercultural communication is said to be the ultimate goal of translation, it is true that some elements in a language may not be translated because meaning dwells more on what is implied rather than what is actually said pragmatic import. 


\section{Works Cited}

1. Adami, A. G., Mihaescu, R., Reynolds, D. A., \& Godfrey, J. J. (2003). Modeling prosodic dynamics for speaker recognition. In Proceedings of Acoustics, Speech, and Signal Processing (ICASSP'03), Vol. 4, 788- 791.

2. Baker, M (ed.) (1998). Routledge Encyclopedia of Translation Studies. London and New York: Routledge.

3. Beckman, M. E., \& Edwards, J. (1990). Lengthenings and shortenings and the nature of prosodic constituency. In J. Kingston and M.E. Beckman (Eds.), Papers in Laboratory Phonology I: Between the grammar and physics of speech, (pp. 152-178). Cambridge: Cambridge University Press.

4. Calhoun, S. (2006). Information structure and the prosodic structure of English: a probabilistic relationship. (Unpublished doctoral dissertation). University of Edinburgh.

5. Cole, J., Mo, Y., \& Baek, S. (2010). The role of syntactic structure in guiding prosody perception with ordinary listeners and everyday speech. Language and Cognitive Processes, 25.7, 1141 - $1177 . \quad$ doi: $10.1080 / 01690960903525507$.

6. Enani, M. (2020). On Translating Style into Arabic and into English, Cairo: Longman.

7. Fromkin, V\&Rodman R (1983). An Introduction to Language. New York: CBS Publishing Japan.

8. Markus, M (2006). "English and German Prosody: A contrastive Comparison." Yuji Kawaguchi, Iván Fónagy and Tsunekazu Moriguchi (eds.). Prosody and Syntax: 
CrossLinguistic Perspectives. John Benjamins B.V. 103124.

9. Perego, E (2003). "Evidence of Explicitation in Subtitling: Towards A categorization." Across Languages and Cultures 4. 63-88.

10.Scott-Tennent, Christopher et al. (2000). "Translation Strategies and Translation Solutions: Design of a Teaching Prototype and Empirical Study of its Results. " Allison Beeby et al. (eds.). Investigating Translation. Amsterdam \& Philadelphia: Benjamins. 108-116.

11.Shapiro, K. Jay. (1948). A bibliography of modern prosody. Baltimore: Johns Hopkins Press.

12.Stockwell, P. (2012), Cognitive Poetics: An Introduction, London, Routledge.

13.Zitawi, J (2003). "English-Arabic Dubbed Children's Cartoons: Strategies of Translating Idioms." Across Languages and Cultures 4: 2. 237-251.

14.صفاء خلوصي ، فن التقطيع الثعري و القافية ، 1966. 


\section{ترجمة الأوزان الثعرية في اللغة الإنجليزية والعربية آية عوض شحاته مبروك}

\section{مستخلص:}

علم العروض هو العلم المعني ببحور و أوزان الثـعر العربي، وأول من

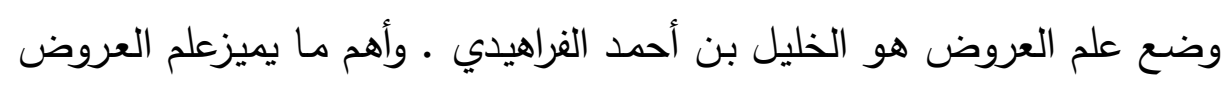
هو الاعتماد الكلي على كيفية نطق الكلمة و ليس على كتابتها ـ و تعتمد بحور الثـعر العربـي على الميزان الصـرفي للكلمـة العربيـة ( تفعيلتها ) مرتكزة علي الأسـاس ( فعل ) • و تتشكل بحور الثعر العربي من كون الكلمات في اللغـة العربيـة تتألف من قسمين : متحركات و سـاكنات و تعتمد على نطقنا للكلمـة بحيث أن كل حرف لا ينطق - رغم كتابته - لا يحسب ضمن الوزن الشعري . وبذلك أسس الفراهيدي بحورا للشعر وأوجد تفعيلات معينـة ثابتة مثل: فاعلن، مفاعيلن، مفاعلتن، متفاعلن، مفعولات، فاعلاتن، مستفعلن، فاعلاتن، مستفعلن و بحور الثعر العربي المشهوة هي : بحر الطويل ، بحر البسيط ، بحر المديد ، بحر الوافر ، بحر الكامل ، بحر الرمل ، بحر الرجز ، بحر الهزج ، بحر ل السريع ، بحر الخفيف ، بحر المنسرح ، بحر المجتث ، بحر المقتضب ، بحر المضارع ، بحر المتقارب ، بحر المتدارك.

وكون الفرق شاسع بين تاريخ اللغة العربية و تاريخ اللغة الانجليزيـة اذ أن الأولى موغلة بالقدم قياسا بالثانية وبذللك فإن اللغة الانجليزية تفتقد ذلك التدوين المقدس الذي حظيت به لغات معينة كالعربية و العبرية و اللاتينية. كما يقاس لهاس الوزن الثعري ( rhythm / meter ) في اللغة الإنجليزية و معظم اللغات 
الغربية بمجاميع صغيرة من المقاطع تسمى الوحدات ( feet ) و الكلمات تقاس وفقا للمقاطع المشددة ( stressed syllables ) و غير المشددة بها و هو المعيار في الثعر الانجليزي تحديدا. (unstressed syllables ) وهذه الدراسة تلخص التالي: - تعتمد التفعيلة في علم العروض العربي على الميزان الصرفي الأساس و هو ( فعل ) بالاعتماد على الحروف الساكنة و المتحركة تم احصـاء تفعيلات أساسية لبحور الثعر العربي مثل (مستفعلن ) و غيرها • بينما ، التفعيلة في علم العروض الانجليزي ترتكز على المقاطع المشددة وغير المشددة و ليس على الحروف الساكنة و المتحركة .

- لكل بحر من بحور الشعر العربي تفعيلاته الثابتة ، و ثباتها هو ثبات لتركيبها و عددها أيضا ـ بينما لبحور الثعر الاتجليزي تفعيلات ثابتة من حيث التركيب و لكنها ليست ثابتة من حيث العدد. - عند ذكر البحر الشعري العربي فـلا حاجـة لذكر عدد تفعيلاته لكونها مشهورة و ثابتة بينما حرية عدد التفعيلات بالشعر الانجليزي تلزم ذكر عددها، و يذكر العدد باللغة اللاتينية.

الكلمات المفتاحيـة: العروض - الإيقاع - الأصوات الساكنة - الأصوات المتحركة - المقاطع الصوتية المنبورة - المقاطع الصوتية غير المنبورة. 